\title{
The relationship between operating cash flow per share and portfolio default probability
}

\author{
Mohammad Khodaei Valahzaghard ${ }^{\mathrm{a}^{*}}$ and Zahra Goodarzi Lemraski ${ }^{\mathrm{b}}$
}

${ }^{a}$ Assist. Prof. \& Faculty Member, Department of Accounting, School of Management and Human Sciences, Tehran North Branch, Islamic Azad University (IAU), Tehran, Iran

${ }^{b}$ M.Sc. Student, Department of Accounting, School of Management and Human Sciences, Tehran North Branch, Islamic Azad University (IAU), Tehran, Iran

\section{H R O N I C L E}

\section{Article history:}

Received June 28, 2013

Received in revised format

19 October 2013

Accepted 2 January 2014

Available online

January 52014

\section{Keywords:}

Default Probability

$M-K M V$

Operating Cash Flow Per Share

$R O A$

\section{A B S T R A C T}

One of the primary duties of the depositary banks is to protect themselves against any possibility of bankruptcy. This requires the identification and measurement of risks, including default risk, which is important given the nature of the activities of banks. This paper presents an empirical investigation to study the relationship between default probability and some financial figures including operating cash flow, liabilities and return of equities. The proposed study of this paper uses historical data of twenty-two firms listed on Tehran Stock Exchange over the period 2008-2012. Default probability as the dependent variable is measured by the method developed by Moody's KMV Company. The study uses linear regression model to examine the relationship between default probability and some independent variables. The results of the present study suggest that there were some reverse relationship between operating cash flow per share, return on equities and default probability. In addition, there was a direct relationship between $\log$ facilities and default probability. However, there was not any relationship between net sales and default probability.

\section{Introduction}

During the past few years, there have been many studies associated with default ratio of corporations (Jonsson \& Fridson, 1996; Behr et al., 2007; Keenan et al., 2000). Altman et al. (2005) analyzed the association between default and recovery rates on credit assets and tried to describe this critical relationship. They investigated recovery rates on corporate bond defaults over the period 1982-2002. The econometric univariate and multivariate models indicated a substantial portion of the variance in bond recovery rates aggregated across seniority and collateral levels. They detected that recovery rates were a function of supply and demand for the securities, with default rates playing essential role.

*Corresponding author. Tel: +98-912-3443139

E-mail addresses: m_khodaei@iau-tnb.ac.ir (M. Khodaei Valahzaghard) 
Lu and Tsai (2009) estimated expected default likelihood by examining three structural models presented earlier by Leland and Toft (1996), Ericsson and Reneby (1998) and Fan and Sundaresan (2000). They applied these techniques based on a sample of 628 Taiwaneses companies with capital structures over the period 1995-2006 to forecast default risk of failed firms. Their results indicated that the likelihoods of all models were well over $50 \%$. The accuracy of forecasting for three models were calculated as $66.07 \%, 82.14 \%$ and $75 \%$.

Zeitun et al. (2007) studied the impact of cash flow and free cash flow on corporate failure in the Jordanian market using two samples; matched sample and a cross-sectional time-series over the period 1989-2003. They applied LOGIT models to outline the relationship between firms' financial health and the likelihood of default. The results indicated that there was firm's free cash flow increases corporate failure. They also reported that the firm's cash flow decreases corporate failure. Firms' capital structures were fundamental in forecasting default. Capital structure was observed as the primary factor influencing the probability of default as it impacts a firm's capability to evaluate external sources of funds.

According to Helwege and Kleiman (1996) tried to find out more about different factors explaining the wide swings in the default rate on high yield bonds. They reported that differences in credit quality from year to year could be considered for much of the observed variation in default rates, but economic conditions and the age of bonds were considered as other important factors.

\section{The proposed study}

The proposed study of this paper uses the following to compute default probability $(P D)$ (Witzany, 2009),

$P D_{i, t}=\beta_{0}+\beta_{1}$ OCF Per Share $_{i, t}+\beta_{2}$ Log Net sell $_{i, t}+\beta_{3}$ Log Facilities $_{i, t}+\beta_{4}$ Roe $_{i, t}+\varepsilon_{i, t}$

where $O C F$ represents operating cash flow per share, $R O E$ states for return of equities, Facilities are total loans and finances received, Net Sell also represents total net revenue reported in official statements of the firms for the proposed study. In this survey, we take natural logarithm of Net Sell and Facilities. PD is calculated by KMV-Merton model estimates the market value of debt by applying the Merton (Crosbie \& Bohn, 2003) bond-pricing model. There are three hypotheses associated with the proposed study of this paper as follows,

1. The logarithm of net sales is associated with default probability.

2. The net sales have meaningful relationship with default probability.

3. Return on equities has meaningful relationship with default probability.

The proposed study of this paper has executed on shares of one of Iranian banks named Bank Mellat by taking 110 observations over the period 2008-2012. Table 1 demonstrates the summary of some basic statistics.

\section{Table 1}

The summary of some basic statistics

\begin{tabular}{ccccccc}
\hline Variable & Number & Mean & Standard deviation & Variance & Skewness & Kurtosis \\
\hline PD & 110 & 0.54 & 0.25 & 0.06 & -1.11 & 2.93 \\
OCF/share & 110 & 0.001 & 0.0011 & 0 & 2.04 & 9.34 \\
Log Net sales & 110 & 6.16 & 0.65 & 0.42 & 0.62 & 4.04 \\
Log Facilities & 110 & 5.88 & 0.72 & 0.52 & -0.37 & 4.46 \\
(ROE) & 110 & 0.29 & 0.29 & 0.08 & 1.2 & 16 \\
\hline
\end{tabular}

In addition, Fig. 1 demonstrates the results of default probability calculated based on KMV-Merton. 


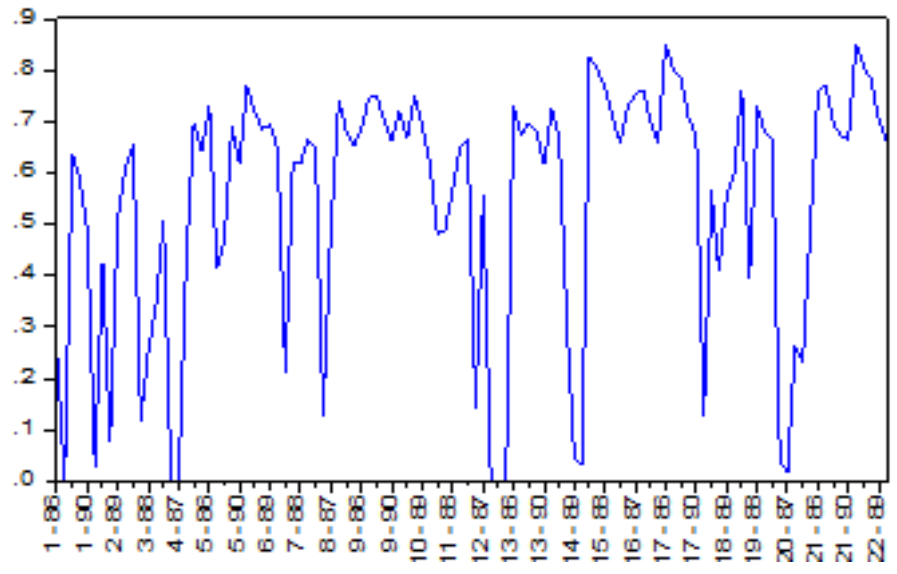

Fig. 1. Default probability

Before, we perform a regression analysis, it is necessary to make sure that all data are normally distributed. Table 2 demonstrates the results of Jarque-Bera test.

\section{Table 2}

The results of Jarque-Bera test

\begin{tabular}{lcc}
\hline Variable & Jarque-Bera & Sig. \\
\hline Default probability & 22.7 & 0 \\
OCF & 261 & 0 \\
Log of Net sales & 12 & 0.002 \\
Log of Facilities & 30 & 0 \\
ROE & 813 & 0 \\
\hline
\end{tabular}

As we can observe from the results of Table 1, all data are normally distributed when the level of significance is five percent. Fig. 1 shows a sample of residuals.

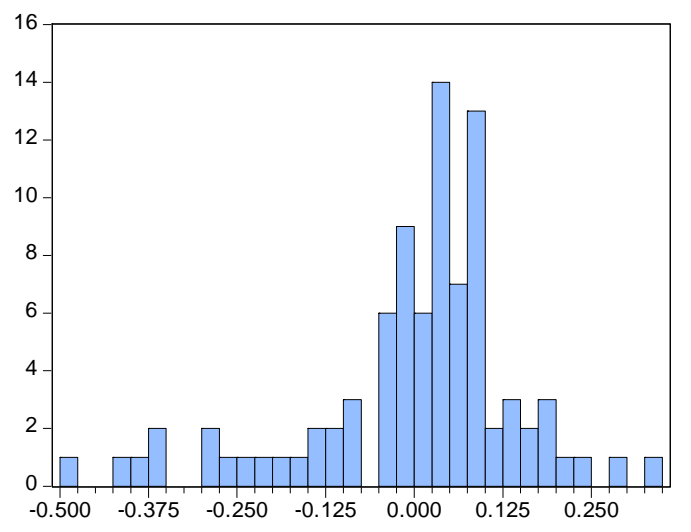

\begin{tabular}{|lc|}
\hline \multicolumn{2}{|l|}{ Series: Standardized Residuals } \\
Sample 1387 1390 \\
Observations 88 \\
Mean & $2.61 \mathrm{e}-12$ \\
Median & 0.032329 \\
Maximum & 0.339531 \\
Minimum & -0.495202 \\
Std. Dev. & 0.152267 \\
Skewness & -1.045584 \\
Kurtosis & 4.456935 \\
& \\
Jarque-Bera & 23.81734 \\
Probability & 0.000007 \\
\hline
\end{tabular}

Fig. 1. The plot of standardized residuals

Before we perform regression analysis, we need to make sure all data are stationary and this could be accomplished through different tests such as augmented Dickey Fuller (ADF) or LLC tests. Some people argue the validity of ADF for small observations and recommend other indicators for testing stationary test. In this paper, we propose to use LLC test to find out whether the nature of data is stationary or not. Table 3 demonstrates the results. 
Table 3

The results of LLC test

\begin{tabular}{ccc}
\hline Variable & LLC & Sig. \\
\hline DF & Statistics & 0 \\
\hline OCF/share & -10.6 & 0 \\
Log (Net Sales) & -4.42 & 0 \\
Log (Facilities) & -9.27 & 0 \\
ROE & -9.36 & 0 \\
\hline
\end{tabular}

In order to choose between Pooled model or Fixed effect model, the proposed study uses Chow test and the results indicated that we need to use Pooled model. Next, we need to make sure there are linear relationships among independent variables. Table 4 demonstrates the results of correlation ratios.

Table 4

The summary of correlations among independent variables

\begin{tabular}{cccccc}
\hline Variable & PD & OCF/share & $\log$ (Sales) & $\log ($ Facilities $)$ & ROE \\
\hline PD & 1 & & & & \\
OCF/share & 0.05 & 1 & & & \\
Log (Sales) & -0.4 & 0.17 & 1 & 1 & \\
Log(Facilities) & -0.37 & 0.19 & 0.28 & 0.2 & 1 \\
ROE & 0.16 & 0.24 & 0.22 & \\
\hline
\end{tabular}

The results of Table 3 clearly show that there were not strong correlations among variables.

\section{The results}

In this section, we present details of our findings on the implementation of the regression equation.

$\mathrm{PD}_{i, t}=-7.7$ OCF Per Share ${ }_{\mathrm{i}, \mathrm{t}}-2.25$ Log Net sell $\mathrm{i}_{\mathrm{i}, \mathrm{t}}+5.16$ Log Facilities ${ }_{\mathrm{i}, \mathrm{t}}-0.02$ Roe $_{\mathrm{i}, \mathrm{t}}+\varepsilon_{\mathrm{i}, \mathrm{t}}$

$\begin{array}{llcc}\text { S.D. }(2.88) & (1.44) & (2.45) & (0.01) \\ \text { t-value } 14.67 & -1.56 & 2.109 & -2.24 \\ \text { Sig. } \quad 0.00 & 0.12 & 0.03 & 0.0254 \\ \text { F-value }=47 \text { Sig. }(0.00) & \text { Durbin-Watson }=2.31 & \end{array}$

Based on the results of Eq. (2), we are now able to examine various hypotheses of the survey.

\subsection{The first hypothesis: The relationship between PD and OCF per share}

The first hypothesis of the survey examines the relationship between default probability and operating cash flow per share. Based on the results of Eq. (2), the coefficient of OCF/share is equal to -7.7, which is statistically meaningful when the level of significance is five percent and we can conclude that as the operating cash flow increases, we may expect the chance of default probability will be reduced.

\subsection{The second hypothesis: The relationship between PD and net sales}

The second hypothesis of the survey examines the relationship between default probability and logarithm of net sales. Based on the results of Eq. (2), the coefficient of log of net sales is not statistically meaningful when the level of significance is five or even ten percent and we cannot 
conclude that there is any relationship between these two variables. Therefore, the second hypothesis of the survey is not confirmed.

\subsection{The third hypothesis: The relationship between $P D$ and $R O E$}

The third hypothesis of the survey examines the relationship between default probability and ROE. Based on the results of Eq. (2), the coefficient of ROE is equal to -0.02 , which is statistically meaningful when the level of significance is five percent and we can conclude that as the operating cash flow increases, we may expect the chance of default probability will be reduced.

\section{Conclusion}

In this paper, we have presented an empirical investigation to study the relationship between operating cash flow per share, logarithm of facilities as well as return on equities. The proposed study has been applied on shares of one of Iranian banks and using regression analysis, the study has confirmed a reverse relationship between PD with OCF as well as ROE. However, the study did not find any meaningful relationship between probability default and logarithm of net sales. Table 5 shows details of our findings.

\section{Table 5}

The summary of testing various hypotheses of the survey

\begin{tabular}{ccccccc}
\hline \multirow{2}{*}{ Hypothesis } & \multicolumn{2}{c}{ Independent/Dependent } & \multicolumn{2}{c}{ Regression analysis } & Result \\
\cline { 2 - 5 } & Independent & Dependent & $\beta=0$ & $\beta \neq 0$ & Relationship & Confirmed \\
\hline Main & Operating per share & Default probability & $\mathbf{X}$ & $\checkmark$ & - & Not confirmed \\
First & Log of Net sales & Default probability & $\checkmark$ & $\mathbf{X}$ & - & Confirmed \\
Second & Log of Facilities & Default probability & $\mathbf{X}$ & $\checkmark$ & $\checkmark$ & Confirmed \\
Third & ROE & Default probability & $\mathbf{X}$ & $\checkmark$ & - & \\
\hline
\end{tabular}

\section{Acknowledgement}

The authors would like to thank the anonymous referees for constructive comments on earlier version of this paper. We are also grateful for the support offered by Bank Mellat for the accomplishment of this work.

\section{References}

Altman, E. I., Brady, B., Resti, A., \& Sironi, A. (2005). The link between default and recovery rates: Theory, empirical evidence, and implications. The Journal of Business, 78(6), 2203-2228.

Behr, A., Kamp, A., Memmel, C. \& Pfingsten, A., (2007). Diversification and the banks' risk-returncharacteristics - evidence from loan portfolios of German banks. Discussion Paper, Banking and Financial Studies 2.

Crosbie, P. \& Bohn, J., (2003). Modeling Default Risk, Modeling Methodology. Moody`s KMV Company.

Ericsson, J., \& Reneby, J. (1998). A framework for valuing corporate securities. Applied Mathematical Finance, 5, 143-163.

Fan, H., \& Sundaresan, S. (2000). Debt valuation, renegotiations and optimal dividend policy. Review of Financial Studies, 13(4), 1057-1099.

Helwege, J., \& Kleiman, P. (1996). Understanding aggregate default rates of high yield bonds. Current Issues in Economics and Finance, 2(6). 
Jonsson, J. G., \& Fridson, M. S. (1996). Forecasting default rates on high-yield bonds. The Journal of Fixed Income, 6(1), 69-77.

Keenan, S. C., Hamilton, D. T., \& Berthault, A. (2000). Historical default rates of corporate bond issuers, 1920-1999. Moody's Investors Services.

Leland, H. E. (2002). Prediction of expected default frequencies in structural models of debt. Working paper, UCLA, Berkeley.

Lu, S. L., \& Tsai, P. C. (2009). How to gauge the default risk? An empirical application of structuralform models. International Research Journal of Finance and Economics, (29), 227-237.

Witzany, J., (2009). Definition of default and quality of scoring functions. Working Paper, University of Economics-Prague.

Zeitun, R., Tian, G., \& Keen, K. (2007). Default probability for the Jordanian companies: A test of cash flow theory. International Research Journal of Finance and Economics, 8, 147-162 